\title{
Screening of the in vitro antileishmanial activities of compounds and secondary metabolites isolated from Maytenus guianensis Klotzsch ex Reissek (Celastraceae) chichuá Amazon
}

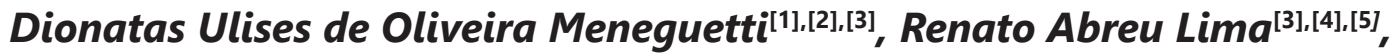 \\ Fernanda Bay Hurtado ${ }^{[3],[6], ~ G u i l h e r m e ~ M a t o s ~ P a s s a r i n i ~}{ }^{[1],[3], ~ S h a r o n ~ R o s e ~ A r a g a ̃ o ~}$ \\ Macedo $^{[1],[7], ~ N e u z a ~ B i g u i n a t i ~ d e ~ B a r r o s ~}{ }^{[4],[7]}$, Flávio Augusto de Souza Oliveira ${ }^{[1],[3],[8] \text {, }}$ \\ Patrícia Soares de Maria de Medeiros ${ }^{[9]}$, Júlio Sancho Linhares Teixeira Militão ${ }^{[3],[10],}$ \\ Roberto Nicolete ${ }^{[1],[4],[7]}$ and Valdir Alves Facundo ${ }^{[1],[3],[4],[10]}$
}

\begin{abstract}
[1]. Programa de Pós Graduação em Biologia Experimental, Universidade Federal de Rondônia, Porto Velho, Rondônia, Brasil. [2]. Laboratório de Fisiofarmacologia, Colégio de Aplicação, Universidade Federal do Acre, Rio Branco, Acre, Brasil. [3]. Laboratório de Química de Produtos Naturais, Universidade Federal de Rondônia, Porto Velho, Rondônia, Brasil. [4]. Programa de Pós Graduação em Biodiversidade e Biotecnologia da Amazônia Legal, Manaus, Amazonas, Brasil. [5]. Instituto de Natureza e Cultura, Universidade Federal do Amazonas, Benjamin Constant, Amazonas, Brasil. [6]. Departamento de Engenharia de Pesca e Aquicultura, Universidade Federal de Rondônia, Presidente Médici, Rondônia, Brasil. [7]. Laboratório de Biotecnologia Aplicada à Saúde, Fundação Oswaldo Cruz de Rondônia, Porto Velho, Rondônia, Brasil. [8]. Laboratório de Quimioterapia da Malária, Fundação Oswaldo Cruz de Rondônia, Porto Velho, Rondônia, Brasil. [9]. Departamento de Ciências Biológicas, Universidade Federal de Rondônia,Porto Velho, Rondônia, Brasil. [10]. Departamento de Química, Universidade Federal de Rondônia, Porto Velho, Rondônia, Brasil.
\end{abstract}

\begin{abstract}
Introduction: Maytenus guianensis is a member of the Celastraceae family that is used in traditional medicine, particularly for its anti-parasitic and anti-cancer effects. To explore the ethnopharmacological potential of this plant, the present study was designed to screen the in vitro antileishmanial activities of extracts and compounds isolated from M. guianensis. Methods: Maytenus guianensis stems and leaves were extracted in acetone, followed by the preparation of eluates and isolation of secondary metabolites using chromatography on a glass column with silica gel as the fixed phase. The chemical components were identified using spectroscopic methods, including one- and two-dimensional nuclear magnetic resonance of hydrogen-1 and carbon-13, mass spectroscopy, and infrared spectroscopy. The anti-Leishmania amazonensis activities of these eluates and compounds were evaluated by direct promastigote counting and viability assays. Results: It was found that the hexane bark eluate produced the strongest anti-L. amazonensis effect, with $90-100 \%$ inhibition of the promastigote form. The isolated metabolite that produced the best result was tingenone $\mathrm{B}$, followed by a compound formed by the union of tingenone and tingenone $\mathrm{B}$ ( $80-90 \%$ inhibition). Conclusions: Maytenus guianensis shows anti-parasite activity that warrants further investigation to determine the mechanisms underlying this antileishmanial effect and to evaluate the pharmacological potential of these eluates and isolated secondary metabolites, while minimizing any adverse effects.
\end{abstract}

Keywords: Triterpenes. Leishmania amazonensis. Chemotherapy. Ethnopharmacology.

\section{INTRODUCTION}

Previous studies have indicated the popularity of plantbased treatments for a range of parasitic diseases, including leishmaniasis. Many compounds isolated from plants have shown promising anti-protozoan activities; these include chalcones, alkaloids, naphthoquinones, lignans, neolignans,

Corresponding author: Dr. Dionatas Ulises de Oliveira Meneguetti. e-mail: dionatas@icbusp.org

Received 6 May 2016

Accepted 26 July 2016 and terpenes ${ }^{(1)(2)(3)(4)(5)}$. However, a large number of medicinal plants remain to be scientifically evaluated and studies have indicated that the active constituents of more than $95 \%$ of endemic Brazilian species have not yet been identified ${ }^{(6)(7)(8)}$. This represents a potentially exploitable pharmacological and economic resource, particularly for Amazonian plant species ${ }^{(8)(9)}$, many of which have not even been cataloged ${ }^{(10)}$.

Numerous species of Amazonian plants have medicinal properties, including those belonging to the therapeutically important Celastraceae family; these have a range of pharmacological activities such as anti-ulcer, insecticide, immunosuppressant, anti-rheumatic, antibacterial, anti- 
parasitic, and anti-cancer effects ${ }^{(11)(12)(13)}$. In Brazil, this family is represented by four genera: Austroplenckia, Franhofera, Maytenus, and Salacia ${ }^{(14)}$. The Maytenus genus is the largest of these and approximately 200 species have been identified in Brazil ${ }^{(15)}$, representing almost $40 \%$ of the known Maytenus species $^{(16)}$. In the Northern Amazon region, the Maytenus guianensis species in particular has been used in traditional medicine for the treatment of various diseases and for its antiparasitic effects ${ }^{(12)}(17)$. The present study therefore aimed to conduct an in vitro screening of the antileishmanial activities of extracts and compounds isolated from M. guianensis.

\section{METHODS}

\section{Collection and identification of plant material}

Maytenus guianensis stem bark and leaves were collected in the Adolpho Ducke Forest Reserve, located at Km 26 of the Manaus-Itacoatiara Road (AM-010) (latitude $02^{\circ} 53$ 'S, longitude $59^{\circ} 58^{\prime} \mathrm{W}$ ). The identification of this species was carried out in the Herbarium of the National Institute for Amazonian Research [Instituto Nacional de Pesquisas da Amazônia (INPA)], voucher specimen number 188.485 .

\section{Preparation of extracts and eluates}

The stem bark samples were dried in an oven (ET-394/2, Tecnal) with forced ventilation at $50^{\circ} \mathrm{C}$ for $48 \mathrm{~h}$ prior to scraping them to remove the bark and increase the contact surface. This produced $1.9 \mathrm{~kg}$ of material, which was extracted three times with acetone $(3 \mathrm{~L} \times 3)$ at room temperature for $72 \mathrm{~h}$ per extraction. The extracts were filtered and the solvent was evaporated using a rotaevaporator (ET-211, Tecnal) to produce $200 \mathrm{~g}$ gross acetone stem bark extract (ASB). Eluates were prepared from $50 \mathrm{~g}$ EBC and fractionated using column chromatography with silica gel and elution using hexane and ethyl acetate. This produced 14.42g hexane eluate of bark (HEB) and $25.81 \mathrm{~g}$ ethyl acetate eluate of bark (EAEB).

The leaf samples were dried in an oven (ET-394/2, Tecnal) with forced ventilation at $50^{\circ} \mathrm{C}$ for $48 \mathrm{~h}$ and subsequently crushed to generate a larger contact surface with the solvent. This material $(1.2 \mathrm{~kg})$ was extracted three times with each solvent $(1.5 \mathrm{~L} \times 3)$ in the following order of polarity: hexane, chloroform, ethyl acetate, and ethanol. This produced $8.11 \mathrm{~g}$ hexane eluate of leaves (HEL), $10.77 \mathrm{~g}$ chloroform eluate of leaves (CEL), $3.50 \mathrm{~g}$ ethyl acetate eluate of leaves (EAEL), and 4.61g ethanol eluate of leaves (EEL).

\section{Isolation of secondary metabolites}

The chemical constituents of HEB and HEL were isolated and purified because these eluates produced the best screening results (data shown in the Results section).

The isolation was performed by chromatography on a glass column, using silica gel from Merck and Vetec $(63-200 \mu \mathrm{m})$ as the fixed phase. The length and diameter of the column varied according to the amount of sample and the type of silica employed. For thin-layer chromatography (TLC), silica gel 60 $(2-25 \mu \mathrm{M})$ on Polyester T - 6145 was used (Sigma Chemical Co.) and fluorescence was detected at $250 \mathrm{~nm}$. The solvents used for these chromatographic elutions were hexane, ethyl acetate, and methanol, either pure or combined to produce a polarity gradient. The separated components were revealed by exposing the analytical TLC plates to ultraviolet light at a wavelength of $254 \mathrm{~nm}$ and by spraying them with universal revealer (ethanol:acetic acid:sulfuric acid at 80:10:10), followed by heating in an oven at $100^{\circ} \mathrm{C}$ for about five minutes.

Mass spectra were obtained by electron impact (70 Ev) using gas chromatography-mass spectrometry (Hewlett Packard 5971) with a capillary column $(30 \mathrm{~m} \times 0.25 \mathrm{~mm})$ of dimethylpolysiloxane BD-1, with $\mathrm{He}$ as the carrier gas. The temperatures employed were $250^{\circ} \mathrm{C}$ in the injector and $200^{\circ} \mathrm{C}$ in the detector, while the column changed from $35-180^{\circ} \mathrm{C}$ by $1 \%$ min and from $180-250^{\circ} \mathrm{C}$ by $10^{\circ} \mathrm{C} / \mathrm{min}$.

The structural identification of the isolated chemical constituents of $M$. guianensis was carried out by spectroscopic methods such as one- and two-dimensional nuclear magnetic resonance of hydrogen-1 (NMR- $\left.{ }^{1} \mathrm{H}\right)$ and carbon-13 (NMR- ${ }^{13} \mathrm{C}$ ), mass spectroscopy (MS), and spectroscopy in the infrared region (IR).

\section{Evaluation of antileishmanial activity}

These tests were performed at the Laboratory of Biotechnology Applied to Health, Oswaldo Cruz Foundation Porto Velho Unit, [Fundação Oswaldo Cruz, Unidade de Porto Velho, (FIOCRUZ-RO)], Rondônia. Male mice were obtained from the FIOCRUZ-RO vivarium at 8-10 weeks old. The animals were kept under standard vivarium conditions.

The present study used promastigotes of Leishmania amazonensis (IFLA/BR/67/PH8). Cultures were established from mice that had previously been inoculated subcutaneously with $10^{5}$ promastigotes of $L$. amazonensis in the right hind paw. Two months after infection, the animals were euthanized by cervical dislocation and the legs, with the lesion and necrotic skin, were removed under sterile conditions. The tissue taken from the infected paws was macerated in Roswell Park Memorial Institute medium (RPMI) to obtain amastigotes of L. amazonensis. The resultant material was centrifuged at 1000rpm for $10 \mathrm{~min}$ at $4^{\circ} \mathrm{C}$. The supernatant was carefully removed and the pellet was suspended in RPMI supplemented with $10 \%$ fetal bovine serum. This culture was maintained at $24^{\circ} \mathrm{C}$ for about five days until the amastigotes had progressed to promastigotes.

For the in vitro propagation of promastigotes, stationary phase parasites were diluted in erythrosine B $(0.04 \%)$ and counted in a Neubauer hemocytometer chamber using an optical microscope at $400 \times$ magnification. The red-colored parasites were considered to be dead, while those that were birefringent and mobile were considered to be alive. The average number of live parasites in $1 \mathrm{~mL}$ was calculated using the following formula: number of parasites $=$ average of four quadrants $\times$ the dilution $\times 10^{4(18)}$. After these calculations, $5 \times 10^{5}$ promastigotes/ $\mathrm{mL}$ were placed in RPMI with $10 \%$ fetal bovine serum and the parasites were maintained at $24^{\circ} \mathrm{C}$; these were passed every five days, up to a maximum of 15 days.

The viability of the promastigotes exposed to the compounds was assessed by two methods: direct counting 
and colorimetric assay using MTT ((3-4,5-dimethylthiazol-2-yl)2,5-diphenyltetrazolium bromide). For both methods, the promastigotes were counted using a Neubauer chamber and approximately $5 \times 10^{5}$ early stationary phase $L$. amazonensis promastigotes were incubated with $100 \mu \mathrm{g} / \mathrm{mL}$ of test compound at different concentrations. For both methods, promastigotes incubated in culture medium were used as the negative control and those incubated with pentamidine at $100 \mu \mathrm{g} / \mathrm{mL}$ acted as the positive control. The counting method was conducted using Eppendorf microtubes and the MTT assays were carried out in 96-well cell culture plates. The promastigotes were incubated with the indicated compounds at $25^{\circ} \mathrm{C}$ for $48 \mathrm{~h}$. For the direct counting assay, $10 \mu \mathrm{L}$ of each sample was diluted using erythrosine B $(0.04 \%)$ and counted using the Neubauer chamber hemocytometer, as described above. The results were expressed as percentages. For the MTT assay, the 96-well plate was centrifuged at $1500 \mathrm{rpm}$ for $15 \mathrm{~min}$ at $4^{\circ} \mathrm{C}$ prior to removal of $80 \mu \mathrm{L}$ from each well. The same volume of RPMI medium was then added to each well, followed by $10 \mu \mathrm{L}$ MTT solution $(5 \mathrm{mg} / \mathrm{mL})$. This was incubated for a further $4 \mathrm{~h}$ in the same incubator. The same centrifugation procedure was then performed and $150 \mu \mathrm{L}$ dimethyl sulfoxide (DMSO) was added to the plate. After a further incubation for $1 \mathrm{~h}$ at room temperature, the plates were gently shaken and read spectrophotometrically at $570 \mathrm{~nm}$. The optical density results were expressed as a percentage of the mean optical density of the negative control cells to represent cytotoxicity.

Statistical analyses of the data were performed using oneway analysis of variance (ANOVA) and multiple comparison post hoc Tukey tests. The level of significance considered in all the tests was 0.01 . Graph pad Prism 5.0 software was used to perform these statistical analyses.

\section{Ethicals considerations}

The experiments were performed in accordance with the standards established by the Ethics Committee for Animal Use (CEUA) and the research project was approved by the CEUA of FIOCRUZ-RO under the protocol number: 2013/12.

\section{RESULTS}

\section{Compounds isolated}

Six secondary metabolites were isolated from the HEB: friedelin (Figure 1A), friedelanol (Figure 1B), 16 $\beta$-hydroxyfriedelin (Figure 1C), 29-hydroxyfriedelin (Figure 1D), 22 $\beta$-hydroxytingenone (tingenone B; Figure 1E), and $22 \beta$-hydroxypristimerin (Figure 1F). A seventh compound was formed by the union of two metabolites: tingenone (Figure 1G) and tingenone B.

From HEL, we isolated $\beta$-sitosterol (Figure 1H) and a compound formed by the union of $\alpha$-amyrin (Figure 1I) and $\beta$-amyrin (Figure 1J). All of the metabolites isolated in this study had previously been described as constituents of $M$. guianensis by our group ${ }^{(19)}$. $\beta$-Sitosterol and $22 \beta$-hydroxypristimerin were not tested for antileishmanial activity because they showed poor solubility in the relevant solvents.

\section{Antileishmanial activity}

In the direct counting method, the HEB and EEF eluates solubilized in ethanol showed the best results; these produced $100 \%$ and $>80 \%$ inhibition, respectively (Table 1). Using DMSO as the solvent, the best results were observed using the EAEL eluate ( $>60 \%$ inhibition), CEL, and EEL (both $>50 \%$ inhibition; Table 1). The HEB also produced the best results in the MTT assay, with $>90 \%$ cytotoxicity, followed by HEL (> 60\%; Table 1).

The secondary metabolites that showed the best antileishmanial results were tingenone B (solubilized in ethanol) and the compound formed by the union of tingenone + tingenone B (solubilized in DMSO); both produced $100 \%$ promastigote inhibition in the direct counting method, while the MTT assay indicated $>90 \%$ cytotoxicity for tingenone B and $80 \%$ for tingenone + tingenone B (Table 2).

\section{DISCUSSION}

Hexane eluates of several plant species from the Amazon region have shown anti-parasitic activities against Leishmania promastigotes; these include Annona foetida ${ }^{(20)}$, Garcinia brasiliensis ${ }^{(21)}$, and Lacistema pubescens ${ }^{(2)}$ against L. amazonensis, Gustavia elliptica against L. braziliensis ${ }^{(23)}$, and Guarea kunthiana and Casearia sylvestris against L. donovani ${ }^{(24)}$.

One possible explanation for the antileishmanial activities of these extracts and hexane eluates is the presence of terpenoids. These compounds have shown anti-parasitic efficacy in several studies ${ }^{(3)(4)(5)(13)(25)(26)(27)(28)(29)(30)(31)(32)(33)(34)(35)}$ and are also found in several Maytenus species ${ }^{(19)(36)(37)(38)(39)(40)(41)(42)(43)(44)(45)}$.

Tingenone B showed the best results in the present study and this compound was previously reported to show antiparasitic activity against Trypanosoma cruzi (IC $<0.25 \mu \mathrm{g} / \mathrm{mL}$ ), Trypanosoma brucei (IC $<0.25 \mu \mathrm{g} / \mathrm{mL}$ ), and Leishmania infantum (IC $<0.51 \mu \mathrm{g} / \mathrm{mL})^{(46)}$. Torres-Santos et al. ${ }^{(26)}$ and Teles et al. ${ }^{(29)}$ investigated the effects of isolated triterpenes on promastigotes of $L$. amazonensis and found that the presence of the carboxylic acid grouping was associated with antiprotozoal activity. Pentacyclic triterpenes, with more hydroxyl groups, had greater effects on these promastigotes and this chemical characteristic is also present in tingenone $\mathrm{B}$, which is a pentacyclic triterpene with a quinonamethide skeleton. Other compounds with the same skeleton have shown great potential for the production of potent drugs against leishmaniasis ${ }^{(30)}$ and Chagas disease ${ }^{(30)(47)}$. Previous studies have shown that triterpenoids stimulate granulocytosis and phagocytosis, thus helping to fight infection ${ }^{(48)}$, causing cytoplasmic extravasation, corpuscle formation, and mitochondrial swelling ${ }^{(49)}$.

Another possible explanation for the anti-parasitic activities of these terpenoids is their activation of programmed cell death within the parasites ${ }^{(50)}$ and interference with the parasite cell differentiation process in the host. This is an extremely complex process involving fine regulation of gene expression ${ }^{(51)}$. However, the mechanism of action by which triterpenoids inhibit the growth of Leishmania promastigotes has not yet been fully elucidated ${ }^{(52)}$. 


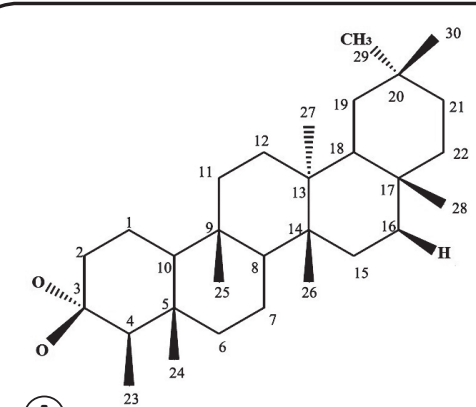

(A)

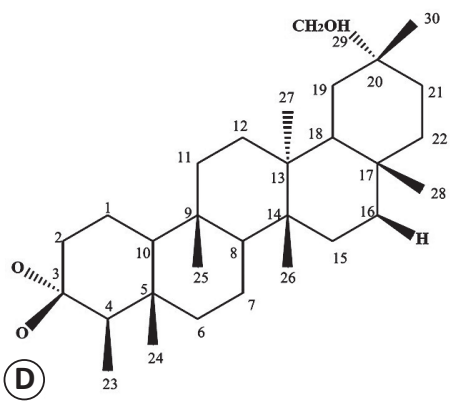

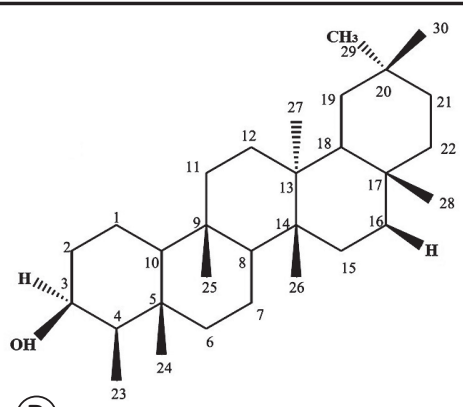

(B)

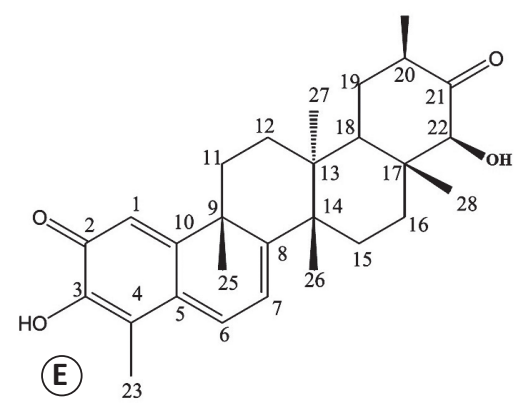

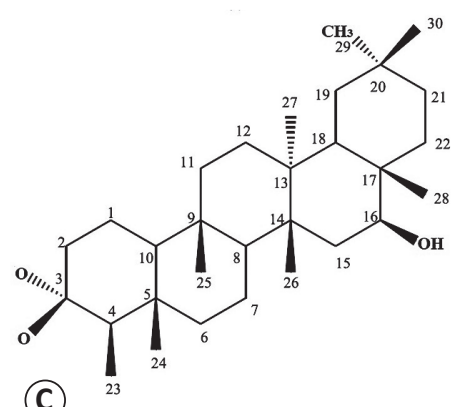

(C)<smiles>CC1=C(C(F)F)C(=O)C=C2C1=CC=C1C23CCC1(C)C1CC(C)(O)C(=O)[C@@H](C)C1(C)CC3</smiles>

(F)

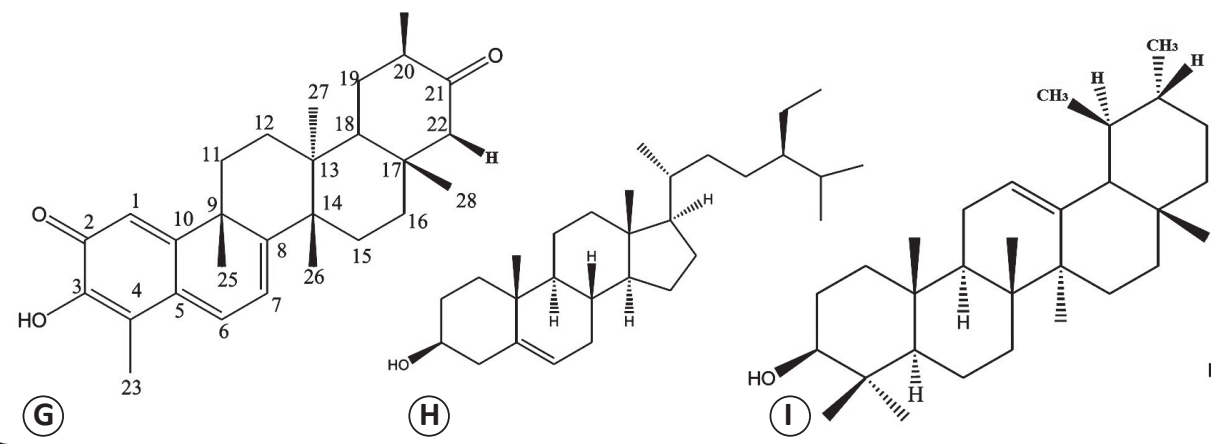

(J)

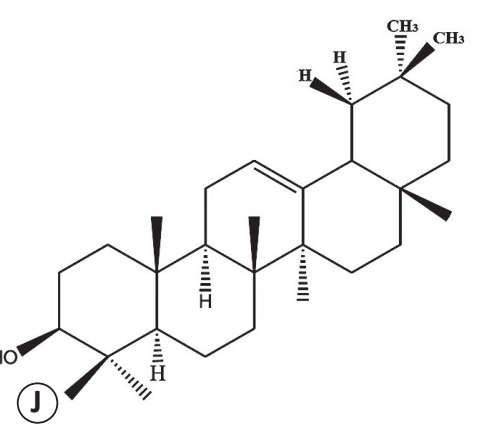

FIGURE 1. Chemical constituents of Maytenus guianensis. (A): friedelin; (B): friedelanol; (C): 16ß-hydroxyfriedelin; (D): 29-hydroxyfriedelin; (E): tingenone;

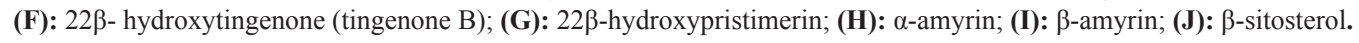

TABLE 1

Antileishmanial activities of the isolated secondary metabolites of Maytenus guianensis.

\begin{tabular}{|c|c|c|c|}
\hline Compounds & Solvent & $\begin{array}{c}\text { Inhibition (\%) } \\
\text { mean (SD) }\end{array}$ & $\begin{array}{c}\text { Cytotoxicity (\%) } \\
\text { mean (SD) }\end{array}$ \\
\hline Control & - & 0 & Not applicable \\
\hline Pentamidine $(5 \mu \mathrm{g} / \mathrm{mL})$ & - & $100^{\mathrm{a}}$ & $92.1 \pm 1.3$ \\
\hline Ethanol (1\%) & - & $44.8 \pm 2.8^{\mathrm{a}, \mathrm{b}}$ & $42.2 \pm 4.1$ \\
\hline EAEB $(100 \mu \mathrm{g} / \mathrm{mL})$ & Ethanol (1\%) & $31.2 \pm 0.6^{\mathrm{a}, \mathrm{b}, \mathrm{c}}$ & $47.9 \pm 3.8$ \\
\hline $\operatorname{EEL}(100 \mu \mathrm{g} / \mathrm{mL})$ & Ethanol (1\%) & $85.2 \pm 0.9^{\mathrm{a}, \mathrm{b}, \mathrm{c}}$ & $10.1 \pm 7.0$ \\
\hline CEL $(100 \mu \mathrm{g} / \mathrm{mL})$ & DMSO $(1.5 \%)$ & $54.3 \pm 7.1^{\mathrm{a}, \mathrm{b}, \mathrm{c}}$ & $38.7 \pm 1.9$ \\
\hline EAEL $(100 \mu \mathrm{g} / \mathrm{mL})$ & DMSO (1.5\%) & $63.8 \pm 3.2^{\mathrm{a}, \mathrm{b}, \mathrm{c}}$ & $39.2 \pm 0.8$ \\
\hline HEL $(100 \mu \mathrm{g} / \mathrm{mL})$ & DMSO $(1.5 \%)$ & $55.1 \pm 3.1^{\mathrm{a}, \mathrm{b}, \mathrm{c}}$ & $62.2 \pm 9.1$ \\
\hline
\end{tabular}

SD: standard deviation; SDS: sodium dodecyl sulfate; DMSO: dimethyl sulfoxide; HEB: acetone stem bark extract; EAEB: ethyl acetate eluate of bark; EEL: ethanol eluate of leaves; CEL: chloroform eluate of leaves; EAEL: ethyl acetate eluate of leaves; HEL: hexane eluate of leaves; MTT: ((3-4,5-dimethylthiazol-2-yl)-2,5-diphenyltetrazolium bromide). Inhibition was determined using the direct counting method. ${ }^{a} \mathrm{p}<0.01$, as compared to

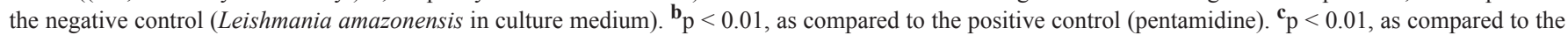
relevant solvent control (ethanol or DMSO). Cytotoxicity was determined using the MTT method. SDS was employed as a non-specific positive control and pentamidine was used as the positive control. The solvent controls were ethanol or DMSO. 
TABLE 2

Antileishmanial activities of isolated secondary metabolites of Maytenus guianensis.

\begin{tabular}{|c|c|c|c|}
\hline Compounds & Solvent & $\begin{array}{c}\text { Inhibition (\%) } \\
\text { mean (SD) }\end{array}$ & $\begin{array}{c}\text { Cytotoxicity (\%) } \\
\text { mean (SD) }\end{array}$ \\
\hline Control & - & 0 & Not applicable \\
\hline Pentamidine $(5 \mu \mathrm{g} / \mathrm{mL})$ & - & $100^{\mathrm{a}}$ & $92.1 \pm 1.3$ \\
\hline Ethanol (1\%) & - & $44.8 \pm 2.8^{\mathrm{a}, \mathrm{b}}$ & $42.2 \pm 4.1$ \\
\hline Tingenone $\mathrm{B}(100 \mu \mathrm{g} / \mathrm{mL})$ & Ethanol (1\%) & $100 \pm 0.1^{\mathrm{a}, \mathrm{b}}$ & $81.9 \pm 0.6$ \\
\hline Tingenone $\mathrm{B}(100 \mu \mathrm{g} / \mathrm{mL})$ & DMSO $(1.5 \%)$ & Not applicable & $97.1 \pm 1.7$ \\
\hline$\alpha$-Amyrin $+\beta$-amyrin $(100 \mu \mathrm{g} / \mathrm{mL})$ & Ethanol (1\%) & $53.2 \pm 0.4^{\mathrm{a}, \mathrm{b}, \mathrm{c}}$ & $10.1 \pm 4.8$ \\
\hline 29-Hydroxyfriedelin $(100 \mu \mathrm{g} / \mathrm{mL})$ & $\operatorname{DMSO}(1.5 \%)$ & $46.2 \pm 4.0^{\mathrm{a}, \mathrm{b}, \mathrm{c}}$ & $34.8 \pm 5.9$ \\
\hline Tingenone + tingenone $\mathrm{B}(100 \mu \mathrm{g} / \mathrm{mL})$ & DMSO $(1.5 \%)$ & $100 \pm 0.0^{\mathrm{a}, \mathrm{c}}$ & $88.7 \pm 1.2$ \\
\hline
\end{tabular}

SD: standard deviation; SDS: sodium dodecyl sulfate; DMSO: dimethyl sulfoxide; MTT: ((3-4,5-dimethylthiazol-2-yl)-2,5-diphenyltetrazolium bromide). Inhibition was determined using the direct counting method. ${ }^{\mathrm{a}} \mathrm{p}<0.01$, as compared to the negative control (Leishmania amazonensis in culture medium). $\mathbf{b}_{\mathrm{p}}<0.01$, as compared to the positive control (pentamidine). ${ }^{\mathbf{c}} \mathrm{p}<0.01$, as compared to the relevant solvent control (ethanol or DMSO). Cytotoxicity was determined using the MTT method. SDS was employed as a non-specific positive control and pentamidine was used as the positive control. The solvent controls were ethanol or DMSO.

The present study found that the M. guianensis HEB showed the strongest anti-L. amazonensis activity, with 90$100 \%$ inhibition of the promastigotes. Among the secondary metabolites, tingenone $\mathrm{B}$ produced the best result, followed by tingenone + tingenone B (80-90\% inhibition). These findings indicate that $M$. guianensis has anti-parasitic potential and warrants future studies to elucidate this antileishmanial mechanism of action and to evaluate the cytotoxic and genotoxic potential of eluates and isolated secondary metabolites from this plant, in order to fully exploit its pharmacological efficacy and minimize any adverse effects.

\section{Acknowledgments}

Federal University of Rondônia [Universidade Federal de Rondônia (UNIR)]; Federal University of Acre [Universidade Federal do Acre (UFAC)] and Oswaldo Cruz Foundation [Fundação Oswaldo Cruz (FIOCRUZ)].

\section{Conflict of Interest}

The authors declare that there is no conflict of interest.

\section{Financial Support}

Coordination of Higher Education Personnel Training [Coordenação de Aperfeiçoamento de Pessoal de Nivel Superior (CAPES)] e National Council for Scientific and Technological Development [Conselho Nacional de Desenvolvimento Científico e Tecnológico (CNPq)].

\section{REFERENCES}

1. Quellette M, Drummelsmith J, Papadoupolou B. Leishmaniasis: drugs in the clinic, resistance and new developments. Drug Resist Update 2004; 7:257-266.

2. Singh S, Sivakumar R. Challenges and new discoveries in the treatment of leishmaniasis. J Infect Chemother 2004; 10:307-315.

3. Bezerra WS, Meneguetti DUO, Camargo LMA. A busca de fármacos para tratamento da Tripanossomíase Americana: 103 anos de negligência. Saúde (Santa Maria) 2012; 38:9-20.

4. Meneguetti DUO, Cunha RM, Lima RA, Oliveira FAS, Medeiros DSS, Passarini GM. Antimalarial ethnopharmacology in the Brazilian Amazon. Rev Ciênc Farm Básica Apl 2014; 35:577-587.

5. Meneguetti DUO, Lima RA, Macedo SRA, Barros NB, Facundo JB, Militao JSLT, et al. Plantas da Amazônia brasileira com potencial leishmanicida in vitro. Rev Patol Trop (on line) 2015; 44:359-374.

6. Fão F, Zan RA, Brondani FMM, Ramos LJ, Meneguetti DUO. Análise do potencial mutagênico da seiva da casca de Croton lechleri (Müll. Arg), no Estado de Rondônia, Amazônia Ocidental. SaBios Rev Saúde e Biol 2012; 7:91-98.

7. Meneguetti DUO, Lima RA, Silva JB, Silva RP, Pagotto RC, Facundo VA. Análise citotóxica e mutagênica do extrato aquoso de Maytenus guyanensis Klotzsch Ex Reissek (Celastraceae) chichuá (xixuá) amazônico. Ciên Nat 2014; 36:301-309.

8. Meneguetti DUO, Lima RA, Silva FC, Passarini GM, Facundo $\mathrm{JB}$, Pagotto RC, et al. Acute genotoxicity analysis in vivo of the aqueous extract of Maytenus guyanensis Amazonian chichuá. Rev Bras Farmacogn 2015; 25:164-169.

9. Cechinel Filho V, Yunes RA. Estratégias para a obtenção de compostos farmacologicamente ativos a partir de plantas 
medicinais - Conceitos sobre modificação estrutural para otimização da atividade. Quím Nova 1998; 21:99-105.

10. Abreu AS, Barbosa PS, Müller AH, Guilhon GMSP. Constituintes químicos do caule e das cascas do caule de Croton pullei var Glabrior (Euphorbiaceae). Rev Virt de Inic Acad da UFPA 2001; 1:1-9.

11. Fonseca APND, Silva GDF, Carvalho JJ, Salazar GDCM, Duarte LP, Silva RP, et al. Estudo fitoquímico do decocto das folhas de Maytenus truncata Reissek e avaliação das atividades antinociceptiva, antiedematogênica e antiulcerogênica de extratos do decocto. Quím Nova 2007; 30:842-847.

12. Macari PAT, Portela CN, Pohlit AM. Antioxidant, cytotoxic and UVB-absorbing activity of Maytenus guyanensis Klotzch. (Celastraceae) bark extracts. Acta Amaz 2006; 36:513-518.

13. Meneguetti DUO, Facundo VA. Análise genotóxica e antiparasitária de extratos e substâncias isoladas de Maytenus guianensis Klotzsch ex Reissek (Celastraceae), Chichuá (Xixuá) amazônico. Rev Pan-Amaz Saude 2015; 6:69-70.

14. Oliveira DM, Silva GDF, Duarte LP, Vieira-Filho SA. Chemical constituints isolated from roots os Maytenus acantophylla Reissek (Celastraceae). Biochem Syst Ecol 2006; 34:661-665.

15. Negri MLS, Possamai JC, Nakashima T. Atividade antioxidante das folhas de espinheira-santa - Maytenus ilicifolia Mart. ex Reiss., secas em diferentes temperaturas. Rev Bras Farmacogn $2009 ; 19: 553-556$

16. Carvalho-Okano RM, Leitão-Filho HF. O gênero Maytenus Mol. emend. Mol. (Celastraceae) no Brasil extra-amazônico. In: Reis MS, Silva SR, organizadores. Conservação e uso sustentável de plantas medicinais e aromáticas: Maytenus spp. Espinheira Santa. IBAMA, Brasília: 2004. p.11-51

17. Revilla J. Apontamentos para a cosmética amazônica. SEBRAEINPA, Manaus: 2002.

18. Silva-Jardim I, Horta MF, Ramalho-Pinto FJ. The Leishmania chagasi proteasome: role in promastigotes growth and amastigotes survival within murine macrophages. Acta Trop 2004; 91:121-130.

19. Facundo VA, Meneguetti DUO, Militão JSLT, Lima RA, Hurtado FB, Casseb AA, et al. Chemical constituents from Maytenus guianensis Klotzsch ex Reissek (Celastraceae) Amazon Rainforest. Biochem Syst Ecol 2015; 58:270-273.

20. Costa EV, Pinheiro MLB, Xavier CM, Silva JRA, Amaral ACF, Souza ADL, et al. A pyrimidine- $\beta$-carboline and other alkaloids from Annona foetida with antileishmanial activity. J Nat Prod 2006; 69:292-294.

21. Pereira IO, Assis DM, Juliano MA, Cunha RL, Barbieri CL, do Sacramento LV, et al. Natural products from Garcinia brasiliensis as Leishmania protease inhibitors. J Med Food 2011; 14:557-562.

22. da Silva JM, Antinarelli LM, Pinto NC, Coimbra ES, de Souza-Fagundes EM, Ribeiro A, et al. HPLC-DAD analysis, antileishmanial, antiproliferative, and antibacterial activities of Lacistema pubescens: an Amazonian medicinal plant. Biomed Res Int 2014; 2014:545038.

23. Almeida MFO, De Melo ACR, Pinheiro MLB, Silva JRA, De Souza ADL, Barison A, et al. Constituintes químicos e atividade leishmanicida de Gustavia elliptica (lecythidaceae). Quim Nova 2011; 34:1182-1187.

24. Mesquita ML, Desrivot J, Bories C, Fournet A, Paula JE, Grellier $\mathrm{P}$, et al. Antileishmanial and trypanocidal activity of Brazilian Cerrado plants. Mem Inst Oswaldo Cruz 2005; 100:783-787.

25. Maes L, Germonprez N, Quirijnen L, Van Puyvelde L, Cos P, Vanden Berghe D. Comparative activities of the triterpene saponin maesabalide III and liposomal amphotericin B (AmBisome) against Leishmania donovani in hamsters. Antimicrob Agents Chemother 2004; 48:2056-2060.

26. Torres-Santos EC, Lopes D, Oliveira RR, Carauta JP, Falcao CA, Kaplan MA, et al. Antileishmanial activity of isolated triterpenoids from Pourouma guianensis. Phytomedicine 2004; 11:114-120.

27. Sülsen VP, Frank FM, Cazorla SI, Anesini CA, Malchiodi EL, Freixa B, et al. Trypanocidal and leishmanicidal activities of sesquiterpene lactones from Ambrosia tenuifolia Sprengel (Asteraceae). Antimicrob Agents Chemother 2008; 52:2415-2419.

28. Danelli MG, Soares DC, Abreu HS, Peçanha LM, Saraiva EM. Leishmanicidal effect of LLD-3 (1), a nor-triterpene isolated from Lophanthera lactescens. Phytochem 2009; 70:608-614.

29. Teles CBG, Moreira LS, Silva AAE, Facundo VA, Zuliani JP, Stábeli RG, et al. Activity of the Lupane isolated from Combretum lerosum against Leishmania amazonensis promastigotes. J Braz Chem Soc 2011; 22:936-942.

30. Santos VAFFM, Leite KM, Siqueira MC, Regasini LO, Martinez I, Nogueira CT, et al. Antiprotozoal activity of quinonemethide Triterpenes from Maytenus ilicifolia (Celastraceae). Molecules 2013; 18:1053-1062.

31. Barrera P, Sülsen VP, Lozano E, Rivera M, Beer MF, Tonn C, et al. Natural Sesquiterpene Lactones Induce Oxidative Stress in Leishmania mexicana. J Evid Based Complementary Altern Med 2013; 2013:163404.

32. Begum S, Ayub A, Qamar Zehra S, Shaheen Siddiqui B, Iqbal Choudhary MS. Leishmanicidal Triterpenes from Lantana camara. Chem Biodivers 2014; 11:709-718.

33. de Toledo JS, Ambrósio SR, Borges CH, Manfrim V, Cerri DG, Cruz AK, et al. In vitro leishmanicidal activities of sesquiterpene lactones from Tithonia diversifolia against Leishmania braziliensis promastigotes and amastigotes. Molecules 2014; 19:6070-6079.

34. Silva AA, Morais SM, Falcão MJ, Vieira IG, Ribeiro LM, Viana $\mathrm{SM}$, et al. Activity of cycloartane-type triterpenes and sterols isolated from Musa paradisiaca fruit peel against Leishmania infantum chagasi. Phytomedicine 2014; 21:1419-1423.

35. Bernal FA, Coy-Barrera E. In-silico analyses of sesquiterpenerelated compounds on selected Leishmania enzyme-based targets. Molecules 2014; 19:5550-5569.

36. Pinheiro JA. Análise da Constituição Química da Madeira de Maytenus guianensis Klotzch. Dissertação de Mestrado. Universidade Federal de Minas Gerais, Belo Horizonte: 1980.

37. Gonzalez JG, delle Monache G, delle Monache F, MariniBettolò GB. Chuchuhuasha - a drug used in folk medicine in the Amazonian and Andean areas. A chemical study of Maytenus laevis. J Ethnopharmacol 1982; 5:73-77.

38. Baudouin G, Tillequin F, Koch M, Tran Huu Dau ME, Guilhem J, Jacquemin H. Two new sesquiterpene-ester alkaloids from Maytenus myrsinoides Reiss. (Celastraceae). Heterocycles 1984; 22: 2221-2226.

39. Itokawa $\mathrm{H}$, Shirota $\mathrm{O}$, Morita $\mathrm{H}$, Takeyaa $\mathrm{K}$, Iitakab $\mathrm{Y}$. Sesquiterpene pyridine alkaloids from Maytenus ebenifolia Reiss. X-Ray molecular structure of ebenifoline W-1. J Chem Soc Perkin Trans 1993; 1:1247-1254.

40. Shirota O, Morita H, Takeya H, Itokawa H. Cytotoxic aromatic triterpenes from Maytenus ilicifolia and Mytenus chuchuhuasca. J Nat Prod 1994; 57:1675-1681.

41. Shirota O, Morita H, Takeya K, Itokawa H. Isolation of antitumor substance, dulcitol, from Maytenus ebenifolia. J Nat Prod 1998; 52:184-186.

42. Salazar GDCM, Silva GDF, De Sousa JR. Chemical constituents from bark wood and leaves of Maytenus floribunda (Reiss). Acta Hort 1999; 501:205-208. 
43. Piacente S, De Tommasi N, Pizza C. Laevisines A and B: two new sesquiterpene-pyridine alkaloids from Maytenus laevis. J Nat Prod 1999; 62:161-163.

44. Nakagawa H, Takaishi Y, Fujimoto Y, Duque C, Garzon C, Sato M, et al. Chemical constituents from the Colombian medicinal plant Maytenus laevis. J Nat Prod 2004; 67:1919-1924.

45. Silva MS, Sousa DP, Medeiros VM, Folly MAB, Tavares JF, Barbosa-Filho J. Alkaloid, flavonoids, and pentacyclic triterpenoids of Maytenus obtusifolia Mart. Biochem Sys Ecol 2008; 36:500-503.

46. Maregesi SM, Hermans N, Dhooghe L, Cimanga K, Ferreira D, Pannecouque C, et al. Phytochemical and biological investigations of Elaeodendron schlechteranum. J Ethnopharmacol 2010; 129:319-326.

47. Lião LM, Silva GA, Monteiro MR, Albuquerque S. Trypanocidal activity of quinonemethide triterpenoids from Cheiloclinium cognatum (Hippocrateaceae). Z Naturforsch C 2008; 63:207-210.

48. Akihisa T, Yasukawa K, Oinuma H, Kasahara Y, Yamanouchi S, Takido M, et al. Triterpene alcohols from the flowers of compositae and their anti-inflammatory effects. Phytochemistry 1996; 43:1255-1260

49. Teles CB, Moreira-Dill LS, Silva AA, Facundo VA, de Azevedo $\mathrm{Jr}$ WF, da Silva $\mathrm{LH}$, et al. A lupane-triterpene isolated from Combretum leprosum Mart. fruit extracts that interferes with the intracellular development of Leishmania (L.) amazonensis in vitro. BMC Complement Altern Med 2015; 15:165.

50. Meslin B, Zalila H, Fasel N, Picot S, Bienvenu AL. Are protozoan metacaspases potential parasite killers? Parasit Vectors 2011; 4:26.

51. Duszenko M, Ginger ML, Brennand A, Gualdrón-López M, Colombo MI, Coombs GH, et al. Autophagy in protists. Autophagy 2011; 7:127-158.

52. Lima ER, Moreira LS, Facundo VA, Silva-Jardim I, Teles CBG. Avaliação da bioatividade do extrato etanólico e triterpeno lupano obtidos de Combretum leprosum contra microorganismos. Saber Cient 2011; 3:53-69. 